\title{
Microbial degradation of four biodegradable polymers in soil and compost demonstrating polycaprolactone as an ideal compostable plastic
}

DOI:

10.1016/j.wasman.2019.07.042

\section{Document Version}

Accepted author manuscript

Link to publication record in Manchester Research Explorer

Citation for published version (APA):

Al Hosni, A. S. K., Pittman, J., \& Robson, G. (2019). Microbial degradation of four biodegradable polymers in soil and compost demonstrating polycaprolactone as an ideal compostable plastic. Waste Management, 97, 105-114. https://doi.org/10.1016/j.wasman.2019.07.042

\section{Published in:}

Waste Management

\section{Citing this paper}

Please note that where the full-text provided on Manchester Research Explorer is the Author Accepted Manuscript or Proof version this may differ from the final Published version. If citing, it is advised that you check and use the publisher's definitive version.

\section{General rights}

Copyright and moral rights for the publications made accessible in the Research Explorer are retained by the authors and/or other copyright owners and it is a condition of accessing publications that users recognise and abide by the legal requirements associated with these rights.

\section{Takedown policy}

If you believe that this document breaches copyright please refer to the University of Manchester's Takedown Procedures [http://man.ac.uk/04Y6Bo] or contact uml.scholarlycommunications@manchester.ac.uk providing relevant details, so we can investigate your claim.

\section{OPEN ACCESS}


1 Microbial degradation of four biodegradable polymers in soil and compost demonstrating polycaprolactone as an ideal compostable plastic

4 Asma S. Al Hosni ${ }^{a}$, Jon K. Pittman ${ }^{b, *}$, Geoffrey D. Robson ${ }^{a, 1}$

5

6 a School of Biological Sciences, Faculty of Biology, Medicine and Health, The

7 University of Manchester, Michael Smith Building, Oxford Road, Manchester

$8 \quad$ M13 9PT, UK

$9{ }^{b}$ School of Earth and Environmental Sciences, Faculty of Science and

10 Engineering, The University of Manchester, Michael Smith Building, Oxford

11 Road, Manchester M13 9PT, UK

12

${ }^{1}$ Deceased

${ }^{\star}$ Corresponding author.

Dr Jon Pittman, School of Earth and Environmental Sciences, The University of

17 Manchester, Michael Smith Building, Oxford Road, Manchester M13 9PT, UK;

Tel: +44 161275 5235; Email: jon.pittman@manchester.ac.uk

E-mail addresses: alhosni828@gmail.com (A.S. Al Hosni), jon.pittman@manchester.ac.uk (J.K. Pittman) 
Abstract

Plastics are an indispensable material but also a major environmental pollutant. In contrast, biodegradable polymers have the potential to be compostable. The biodegradation of four polymers as discs, polycaprolactone (PCL), polyhydroxybutyrate (PHB), polylactic acid (PLA) and poly(1,4 butylene) succinate (PBS) was compared in soil and compost over a period of more than 10 months at $25^{\circ} \mathrm{C}, 37^{\circ} \mathrm{C}$ and $50^{\circ} \mathrm{C}$. Degradation rates varied between the polymers and incubation temperatures but PCL showed the fastest degradation rate under all conditions and was completely degraded when buried in compost and incubated at $50^{\circ} \mathrm{C}$ after 91 days. Furthermore, PCL strips showed a significant reduction in tensile strength in just 2 weeks when incubated in compost $>45^{\circ} \mathrm{C}$. Various fungal strains growing on the polymer surfaces were identified by sequence analysis. Aspergillus fumigatus was most commonly 


\section{Introduction}

Over the last six decades, the use of plastic materials has had a major impact on society and has become essential due to their extensive and diverse range of applications. There have been wide spread applications and usage of plastics because of their favourable mechanical and thermal properties and because plastics are cheap to manufacture, are stable and durable. The global production of plastics has increased every year (Tokiwa et al., 2009). For example, the annual production of petroleum-based plastics exceeded 300 million tonnes in 2015 (Emadian et al., 2017). Despite the applications and benefits of plastics, the recalcitrant nature of many plastics means that they stay in the environment for decades or even centuries. As a consequence, significant amounts of plastics accumulate in the environment and in landfills resulting in environmental pollution and waste management issues (Hopewell et al., 2009). Due to the growing environmental problems, biodegradable plastics are considered as one potential solution (Haider et al., 2019; Tokiwa et al., 2009; Zheng et al., 2005).

Biodegradable polymers are polymeric materials that can be decomposed into $\mathrm{CO}_{2}$, methane, water, inorganic compounds or biomass by the action of microbial enzymes (Haider et al., 2019; Laycock et al., 2017; Song et al., 2009). The chains of these polymers can also be broken down by nonenzymatic processes, such as chemical hydrolysis (Tokiwa et al., 2009). There are many factors that can affect the degradation of biodegradable polymers such as molecular weight, surface area, and chemical structure of the polymer (Luyt and Malik, 2019; Tokiwa et al., 2009). A number of different types of 
biodegradable polymers have been developed to date and several studies have investigated the degradability of these plastics. For example, polyhydroxybutyrate (PHB) is a naturally occurring polyhydroxyalkanoate-type polyester that is composed of small $\left(\mathrm{C}_{4} \mathrm{H}_{6} \mathrm{O}_{2}\right)$ monomer units (Supplementary Data Table S1), and can be produced from renewable resources such as starch and cellulose. PHB can be degraded by a range of bacterial species through the action of a PHB depolymerase enzyme (Reddy et al., 2003; Shimao, 2001; Tokiwa et al., 2009). In particular, PHB can be degraded in $5-6$ weeks in microbiologically active environments such as compost (Siracusa et al., 2008). Polylactic acid (PLA) is an aliphatic polyester composed of small lactide $\left(\mathrm{C}_{3} \mathrm{H}_{4} \mathrm{O}_{2}\right)$ monomers (Supplementary Data Table $\mathrm{S} 1$ ) that can be produced by the fermentation of materials including starch, molasses and cellulose, and accounts for $24 \%$ of the global production of biodegradable polymers (Haider et al., 2019; Karamanlioglu et al., 2017). PLA can be degraded by abiotic and biotic processes including by a range of microorganisms (Nampoothiri et al., 2010; Shah et al., 2008), and can be fully degraded when compost temperatures reach $60^{\circ} \mathrm{C}$ and above (Pranamuda and Tokiwa, 1999; Shah et al., 2008).

Poly $(1,4$ butylene) succinate (PBS) is also an aliphatic polyester composed of butylene succinate $\left(\mathrm{C}_{8} \mathrm{H}_{12} \mathrm{O}_{4}\right)$ monomers (Supplementary Data Table S1). PBS can also be produced from various recycled materials and can be naturally degraded by bacteria and fungi (Kim et al., 2005). It has been observed that the degradation of PBS was higher in compost compared to natural soil due to the higher temperature and humidity conditions in compost 
97 (Kim et al., 2005). Polycaprolactone (PCL) is a thermoplastic synthetic polymer composed of caprolactone $\left(\mathrm{C}_{6} \mathrm{H}_{10} \mathrm{O}_{2}\right)$ monomers (Supplementary Data Table S1). PCL is compatible with many other polymers and can be used for many applications (Borghesi et al., 2016; Fukushima et al., 2010; Vivi et al., 2019). Studies have reported that PCL is degradable in many natural environments such as soil, seawater and active sludge (Borghesi et al., 2016; Li et al., 2012; Nawaz et al., 2015). The hydrolysable ester linkage of this linear aliphatic polyester makes it susceptible to microbial degradation via lipase and esterase action (Albertsson et al., 1998).

Relatively little is known about the time required for these materials to be fully degraded in soil or compost, or the biotic and abiotic conditions that allow efficient degradation. Moreover, most previous studies have concentrated on monitoring degradation of plastic powders or plastic blends (biodegradable plastics mixed with starch or fibres or any other degradable materials).

Therefore, the aim of this study was to determine the rate of degradation of four polymers, PCL, PHB, PLA and PBS as unblended discs or strips under both soil and compost conditions. These four polymers were chosen as they are among the most widely used by industry (Haider et al., 2019). Polymer degradation was examined over a range of temperatures within soil and compost. These temperatures are representative of mesophilic temperatures $\left(25^{\circ} \mathrm{C}, 37^{\circ} \mathrm{C}\right.$, $45^{\circ} \mathrm{C}$ ), which are typical within temperate soils, and thermophilic temperatures $\left(50^{\circ} \mathrm{C}, 55^{\circ} \mathrm{C}\right)$, which can be achieved within composts. Furthermore, polymer degradation was examined under uncontrolled field soil conditions (Supplementary Data Table S2). 
Various methods can be used to evaluate the degradation of

122

biodegradable polymers including $\mathrm{CO}_{2}$ evolution, clear zone formation, changes in mechanical properties (such as loss of tensile strength) and weight loss measurement (Shah et al., 2008). In this study changes in polymer mechanical properties and weight loss were used to evaluate the biodegradation of PCL, PHB, PLA and PBS (Supplementary Data Table S2). Moreover, this study intended to evaluate the biodegradation of $\mathrm{PCL}$ polymer as different geometric forms; thick discs, thin strips and powder. Finally, morphological and sequencing approaches were used to identify the principal colonising fungi strains and to examine whether some of these strains are important for mediating polymer degradation.

\section{Materials and Methods}

A summary of the different methodological approaches used to examine biopolymer degradation in soil or compost is presented in Supplementary Data Table S2.

\subsection{Plastic materials, soil and compost}

Granules (3- $5 \mathrm{~mm}$ size) of PCL ( $\mathrm{M}_{\mathrm{w}} 80,000$; Sigma-Aldrich, UK), PHB $\left(M_{w} \sim 55,000\right.$; Sigma-Aldrich, UK), PLA $\left(M_{w} \sim 30,000\right.$; Goodfellow Cambridge, UK), and PBS ( $M_{w} \sim 40,000$; Goodfellow Cambridge, UK) were obtained for the preparation of polymer discs or strips (see Supplementary Data Table S1 for polymer granule characteristics). PCL powder with a particle size of $<600 \mu \mathrm{m}$ 
$144\left(\mathrm{M}_{\mathrm{w}}\right.$ 50,000; Polysciences Europe, Germany) was obtained for preparing compost-PCL powder mixes.

Plastic sheets were prepared by melting the polymer granules in a halogen oven for $20 \mathrm{~min}$ at $80^{\circ} \mathrm{C}$ for PCL, $195^{\circ} \mathrm{C}$ for $\mathrm{PHB}, 180^{\circ} \mathrm{C}$ for PLA, and $210^{\circ} \mathrm{C}$ for PBS. Sheet thickness was determined by the depth of the glass casting tray. For soil or compost burial studies, the sheets were cut into either 1 $\mathrm{cm}$ diameter, $3 \mathrm{~mm}$ thick discs for the controlled condition experiments or into 5 $\mathrm{cm}$ diameter, $2.5 \mathrm{~mm}$ thick discs for the environmental burial (uncontrolled conditions) experiments using cork borers. PCL strips for tensile strength measurements were made by melting $12.5 \mathrm{~g}$ of PCL granules in $100 \mathrm{~mL}$ dichloromethane and pouring this into a levelled glass cast to then set to form a sheet with an even thickness of $0.4-0.5 \mathrm{~mm}$. The sheet was cut into $6 \mathrm{~cm} x$ $0.5 \mathrm{~cm}$ strips. All strips had near identical maximum tensile strength characteristics (13.9 $\pm 0.4 \mathrm{MPa})$ indicating high quality control in strip preparation.

Commercial soil and compost (The Compost Shop, UK) was screened to remove large particles and material using a $7 \mathrm{~mm}$ sieve prior to use. The percentage moisture content and the water holding capacity (WHC) for the soil and compost was determined as described previously (Karamanlioglu et al., 2014). The moisture content of the compost and soil was $35 \%$ and $26 \%$, respectively, and the water holding capacity was $75 \%$ and $60 \%$, respectively, and the $\mathrm{pH}$ was 7.1 and 7.0 , respectively. 


\subsection{Biodegradation of plastic discs under controlled conditions}

In order to investigate the biodegradation of the plastics under controlled conditions, rectangular $1 \mathrm{~L}$ plastic boxes (Stewart, UK) with dimensions $16.5 \mathrm{~cm}$ $x 11.5 \mathrm{~cm} \times 5 \mathrm{~cm}$ were filled with $500 \mathrm{~mL}$ of soil or compost and seven preweighed plastic discs were buried vertically at $2 \mathrm{~cm}$ below the surface. The boxes were sealed with lids containing three $1 \mathrm{~cm}$ diameter air holes to allow for gaseous exchange and covered with a single layer of parafilm. Boxes were incubated at $25^{\circ} \mathrm{C}$ or $37^{\circ} \mathrm{C}$ (for soil) or $25^{\circ} \mathrm{C}, 37^{\circ} \mathrm{C}$ or $50^{\circ} \mathrm{C}$ (for compost) for 10 months. A temperature of $50^{\circ} \mathrm{C}$ was not used for soil because soil normally does not reach this temperature. Boxes were weighed every week to determine water loss by evaporation and replaced with sterile water using a fine spray. To determine changes in the weight of the plastic discs, discs were weighed then reburied periodically, every week (for compost) and every 3 weeks (for soil), after the removal of loosely bound soil or compost with a soft brush and excess moisture, weight loss was determined by:

Weight loss $(\%)=\left(\mathrm{W}_{\text {dry }} / \mathrm{W}_{\text {ini }}\right) \times 100$

Where $W_{\text {ini }}$ is the initial weight of the disc before burial and $W_{d r y}$ is the dry weight of disc after burial.

\subsection{Biodegradation of plastic discs in soil under environmental conditions} In order to investigate the biodegradation of the plastics under uncontrolled environmental conditions, plastic discs were buried in the soil in an elevated bed in a field environment (on The University of Manchester campus). 
192 The polymer samples were randomly located within the bed and three replicates

193 for each polymer were sampled then reburied every 2 months for PCL, PBS and 194 PHB, and every 4 months for PLA, over a period of up to 21 months. Unburied 195 control discs were kept in a dry indoor environment and were weighed 196 periodically. Another set of control discs were incubated in sterile water at room 197 temperature over 21 months and their weight was measured at the end of the period to determine if there was any effect of water on the degradation of the polymers. compost and 40 pre-sterilized (70\% ethanol washed) PCL strips were added to each box and buried in the compost. The boxes were sealed with lids containing three $1 \mathrm{~cm}$ diameter air holes to allow for gaseous exchange and covered with a single layer of parafilm. The boxes were incubated at $25^{\circ} \mathrm{C}, 37^{\circ} \mathrm{C}, 45^{\circ} \mathrm{C}$, or $50^{\circ} \mathrm{C}$ for 10 weeks. At each week, four PCL strips were recovered, any compost sticking to the strips was removed and the maximum tensile strength of the strips was measured in order to determine loss of tensile strength during compost incubation. Measurements were performed using a T-series Tensile Test Machine (Tinius Olsen, UK) supported with QMAT Professional software.

212 The load cell was $1 \mathrm{kN}$ with a cross head speed of $10 \mathrm{~mm} \mathrm{~min}^{-1}$. PCL strips were also kept dry in a petri dish at each temperature condition for control comparison. As an additional control, PCL strips were incubated in a compost 
extract. The compost extract was prepared as described previously

216 (Karamanlioglu and Robson, 2013).

217

2.5. Biodegradation of PCL powder in compost under controlled conditions

Rectangular $1 \mathrm{~L}$ plastic boxes (Stewart, UK) were filled with $400 \mathrm{~mL}$ compost that was mixed with $40 \mathrm{~mL}$ PCL granule powder (to give $10 \% \mathrm{PCL}$ in the compost mixture). The boxes were sealed with lids containing three $1 \mathrm{~cm}$ diameter air holes to allow for gaseous exchange and covered with a single layer of parafilm. The boxes were incubated at $25^{\circ} \mathrm{C}, 37^{\circ} \mathrm{C}, 45^{\circ} \mathrm{C}, 50^{\circ} \mathrm{C}$ and $55^{\circ} \mathrm{C}$ for 8 weeks and control boxes were incubated without PCL powder. Samples of compost $(1 \mathrm{~g})$ were recovered every week from three different random locations within each box. The samples $(1 \mathrm{~g})$ were mixed with $5 \mathrm{~mL}$ dichloromethane solvent in a glass tube and left overnight. The solvent was removed from the glass tube (avoiding any soil particles) and the solvent was transferred to a glass petri dish and left until the PCL solidified to produce a plastic sheet. The weight of the produced sheet was measured. This was repeated at each weekly time points for 8 weeks for each of the temperature treatments.

\subsection{Scanning Electron Microscopy}

Polymer discs recovered from compost and soil at all temperatures at random time points were observed for fungal growth by scanning electron microscopy (SEM) (FEI, QUANTA FEG 250, Netherlands). Air dried samples 
were mounted for sputter coating with gold/palladium on a Quorum SC7620 sputter coater. The samples were then imaged at high vacuum at $10 \mathrm{kV}$.

\subsection{Isolation and identification of fungal growth on the surface of polymers} Fungi were recovered from the surface of the polymer discs and this recovery was adapted using a previously described method (Cosgrove et al., 2007; Karamanlioglu et al., 2014). Polymer discs were recovered from all of the compost and soil treatments and placed in $1 \mathrm{~mL}$ phosphate-buffered saline. The surfaces of the discs were then scraped 3 times on both sides using a sterile razor blade. Biomass suspension obtained from the surface of the polymer discs were plated onto Potato Dextrose Agar (PDA) plates supplemented with chloramphenicol $\left(50 \mathrm{~g} \mathrm{~mL}^{-1}\right)$ after serial dilution and incubated at the same temperatures at which the discs were originally incubated.

\subsection{Genomic DNA extraction from fungal mycelia}

Distinct colonies from PDA plates were purified by sub culturing onto fresh PDA plates and incubated at their designated temperatures and then used for DNA was extracted from a loopfull of mycelium or spores exactly as described by Feng et al. (2010) except that the fungal material was homogenised twice for $30 \mathrm{~s}$ at $5000 \mathrm{rpm}$ using a Bead Bug Microtube Homogenizer (Merck, UK) and $0.5 \mathrm{~mm}$ glass beads. DNA was quantified using a Nanodrop ${ }^{\text {TM }} 1000$ (Thermo Fisher Scientific, UK) and stored at $-20^{\circ} \mathrm{C}$ in sterile water until use. 
2.9. DNA amplification and sequencing of rRNA genes to identify fungal isolates In order to identify the fungal isolates, the ITS1-5.8S-ITS2 rRNA gene fragment was amplified using the universal fungal primers (White et al., 1990) ITS1-F (5'-CTTGGTCATTTAGAGGAAGTAA-3') and ITS4-R (5'TCCTCCGCTTATTGATATGC-3'). The PCR mixture contained $25 \mu \mathrm{L}$ MyTaq Red Mix (Bioline, UK), $1 \mu \mathrm{L}$ 100x Bovine Serum Albumin, $5 \mu \mathrm{L}$ of extracted DNA $\left(75-100 n g \mu \mathrm{L}^{-1}\right), 2 \mu \mathrm{L}$ of each primer $(10 \mu \mathrm{M})$ and the total volume made up to $50 \mu \mathrm{L}$ with sterile water. The PCR cycle conditions were 35 cycles of $95^{\circ} \mathrm{C}$ for $1 \mathrm{~min}, 56^{\circ} \mathrm{C}$ for $15 \mathrm{~s}$ and $72^{\circ} \mathrm{C}$ for $10 \mathrm{~s}$. The PCR products were purified using the QIAquick PCR purification kit (Qiagen,UK) according to the manufacturer's instructions. The purified PCR products were sequenced at The University of Manchester DNA sequencing facility. DNA sequences were then viewed using FinchTV and analysed by NCBI BLAST. Fungal strain isolates were identified from identical or closest match sequence present in the GenBank database.

\subsection{Degradation ability of fungal isolates on PCL strips} The capability of fungal isolates recovered from the surface of PCL discs incubated in compost at $50^{\circ} \mathrm{C}$ to degrade PCL strips were determined using modified methods described by Cosgrove et al. (2010) and Crabbe et al. (1994). Wheat grains $(200 \mathrm{~g})$, used as a matrix for fungal growth, were autoclaved in a glass container then $150 \mathrm{~mL}$ of a yeast-extract-salt (YES) medium was added. Fungal isolates, $\mathrm{PCL}(\mathrm{A})$ and $\mathrm{PCL}(\mathrm{B})$, were grown on $\mathrm{PDA}$ media for one week, chopped and added to the sterile wheat-YES medium containers. One container was left uninoculated as a control. The containers were incubated at $50^{\circ} \mathrm{C}$ for 
one week. PCL strips were surface sterilized with $70 \%(\mathrm{v} / \mathrm{v})$ ethanol then added

287 to the container to allow the fungal culture to grow on the strips for 3 weeks.

288 The strips were recovered every 3 days and the tensile strength was measured as described in Section 2.4.

290

291

292

293 using SPSS.

294

295

\section{Results and Discussion}

296

297

298 conditions

The first set of experiments aimed to determine the weight loss of PCL, PHB, PLA and PBS materials in the form of thick discs following burial in compost or soil. Discs were recovered every week from compost and every three weeks from soil that were incubated at $25^{\circ} \mathrm{C}, 37^{\circ} \mathrm{C}$ and $50^{\circ} \mathrm{C}$ (compost only) and the percentage of the original disc weight calculated. All polymers showed degradation in compost at $50^{\circ} \mathrm{C}$ but the fastest rate of degradation occurred with PCL where complete degradation occurred under this condition after 91 days (Fig. 1). While a significant reduction in PCL disc weight was also observed at $25^{\circ} \mathrm{C}$ and $37^{\circ} \mathrm{C}$ in compost (Fig. 1a) and soil (Fig. 2a), the reduction was slower compared to $50^{\circ} \mathrm{C}$ and therefore temperature was a major factor in PCL degradation. PHB discs also showed a significant reduction in weight 
under all conditions, and the rate of degradation at $37^{\circ} \mathrm{C}$ in compost (Fig. 1b) and soil (Fig. 2b) was equivalent to the PCL discs, although there was less reduction of PHB discs in comparison to PCL polymer at other temperatures, particularly at $50^{\circ} \mathrm{C}$ in compost. While no significant change was observed for PLA at $25^{\circ} \mathrm{C}$ and $37^{\circ} \mathrm{C}$ in both compost (Fig. 1C) and soil (Fig. 2C), a significant reduction was observed at $50^{\circ} \mathrm{C}$ in compost, with a degradation profile that was equivalent to the PHB discs. Finally, PBS discs displayed moderate degradation at $50^{\circ} \mathrm{C}$ in compost (Fig. 1d) and $37^{\circ} \mathrm{C}$ in soil (Fig. 2d). Surprisingly, there was no reduction in PBS disc weight at $37^{\circ} \mathrm{C}$ in compost, and there was no significant PBS reduction detected at $25^{\circ} \mathrm{C}$ in either substrate. A summary of the end point data is shown in Supplementary Data Table S3.

The rate of biodegradation of biodegradable plastics is influenced by a number of parameters including molecular structure, molecular weight, degree of crystallinity and melting temperature of the polymer (Chandra and Rustgi, 1998). For example, the presence of specific functional groups within the polymer chain will determine the degree of hydrolysis and therefore rate of degradation (Göpferich, 1996). Likewise, polyesters with side chains with show faster degradation than those without. If polymers such as PCL reduced crystallinity more than other polymers during the incubation period, this would also increase degradation rate (Tsuji and Miyauchi, 2001). Other factors that might also affect the rate of degradation include variation of the incubated environment (soil and compost) in terms of organic and inorganic compositions, the types of degrading microbiota and the incubation temperature (Manna and Paul, 2000). While PCL has the lowest melting temperature $\left(\sim 60^{\circ} \mathrm{C}\right)$ of all the 
334 four polymers (Supplementary Data Table S1) it does not appear that the faster

335 degradation of PCL is simply due to temperature sensitivity since PCL

336 incubation at $50^{\circ} \mathrm{C}$ under dry (no compost/soil) conditions had no significant

337 effect on the polymer. Here, PCL was shown to be degraded far more rapidly

338 than PBS, PLA or PHB and thus is highly susceptible to biodegradation.

339 Likewise, significant degradation of PCL was previously observed in compost at

$34040^{\circ} \mathrm{C}$ after 35 days (Fukushima et al., 2010) and in compost at $58^{\circ} \mathrm{C}$ after 47

341 days (Funabashi et al., 2007). Nishide et al. (1999) also found that PCL showed

342 the fastest degradation rate at $52^{\circ} \mathrm{C}$ in aerobic soil. Therefore, temperature was

343 clearly highly correlated to the rate of PCL degradation. 

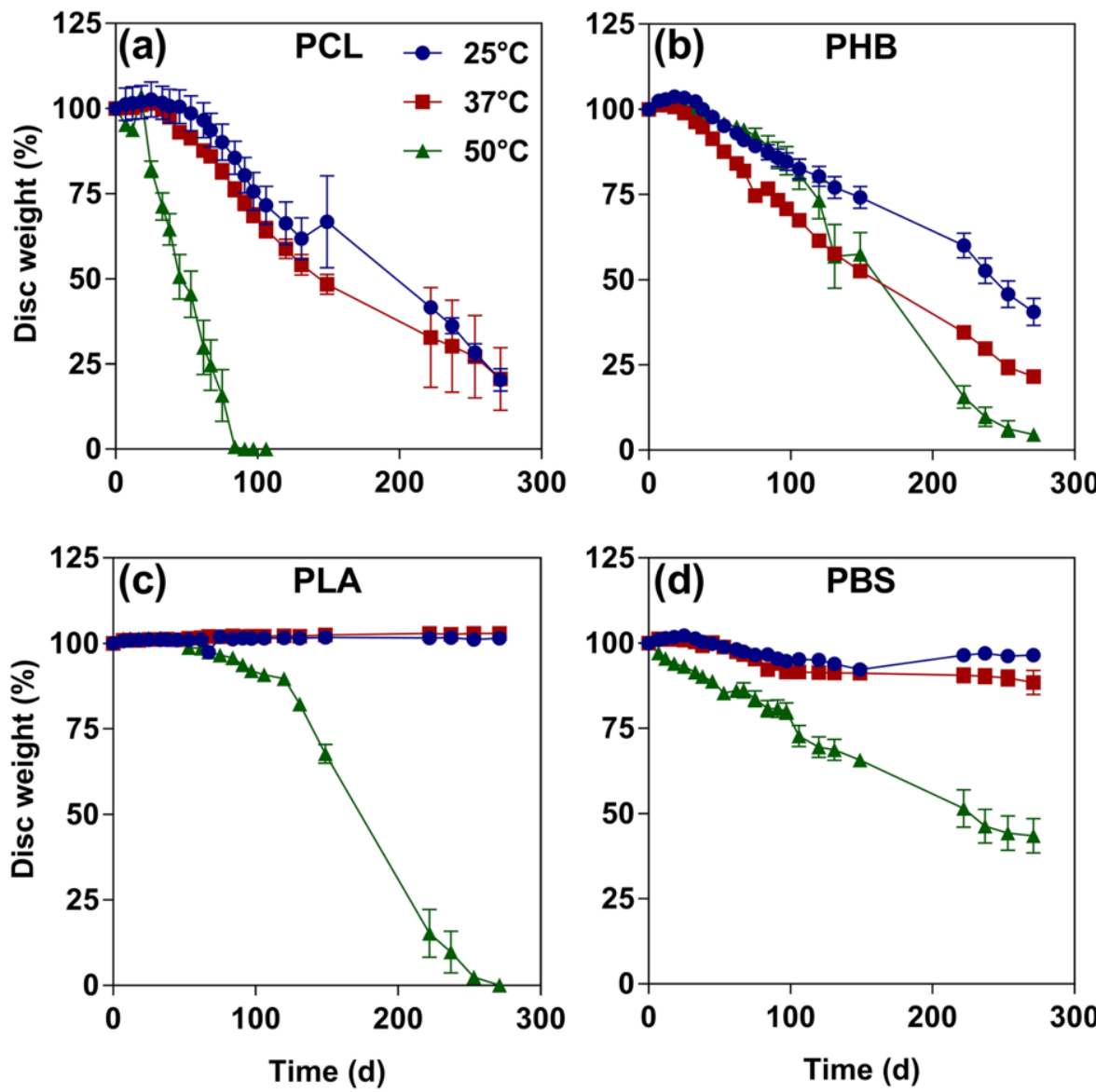

Fig. 1. Weight change over time of polymer discs buried in compost. PCL (a), PHB (b), PLA (c) and PBS (d) discs were buried in compost in a laboratory microcosm and incubated at $25^{\circ} \mathrm{C}, 37^{\circ} \mathrm{C}$ or $50^{\circ} \mathrm{C}$ and the mean weight remaining calculated at approximately $7 \mathrm{~d}$ intervals. All data are mean percentage weight values \pm standard error of the mean of 7 replicate measurements. 

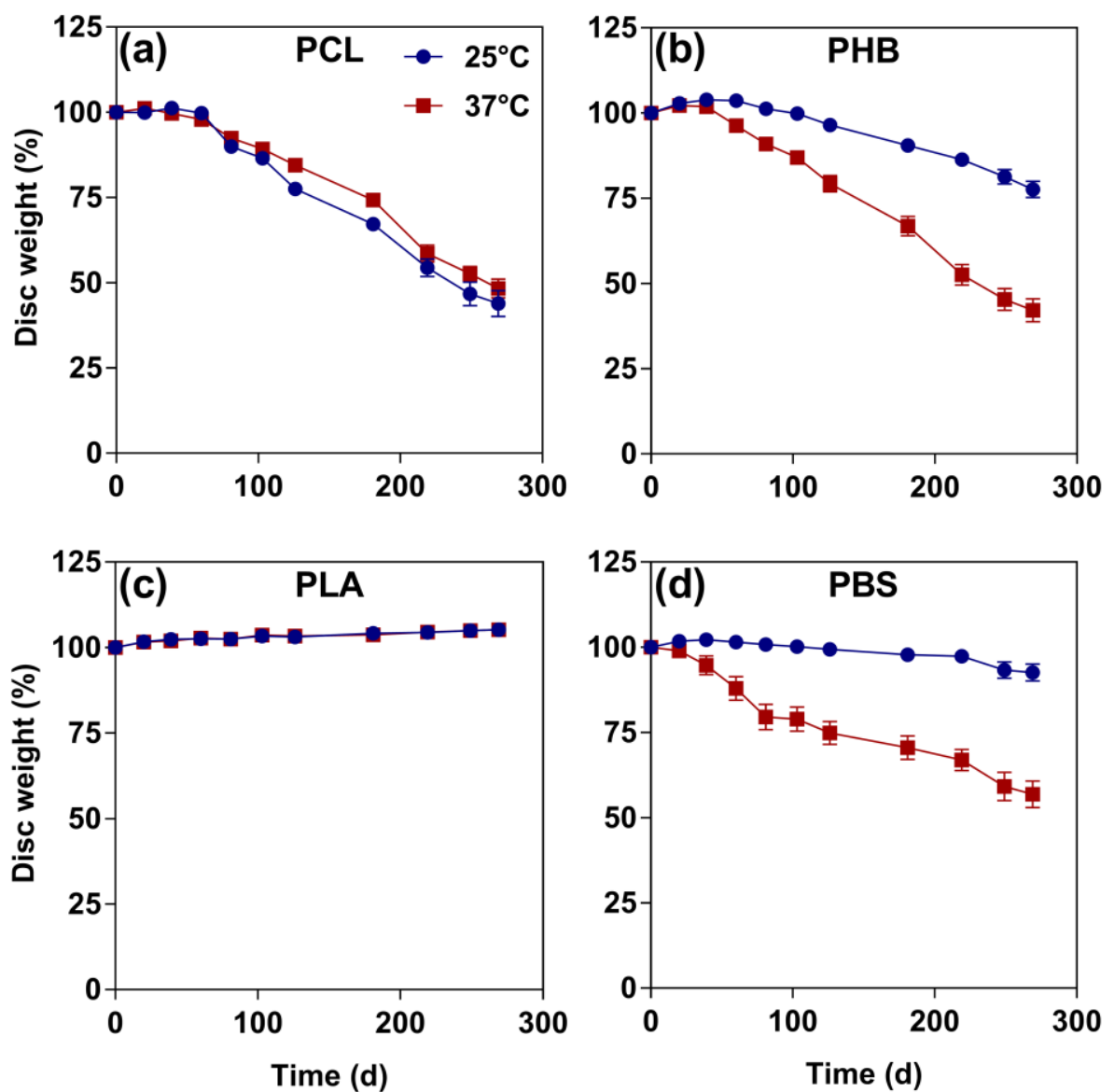

Fig. 2. Weight change over time of polymer discs buried in soil. PCL (a), PHB (b), PLA (c) and PBS (d) discs were buried in soil in a laboratory microcosm and incubated at $25^{\circ} \mathrm{C}$ or $37^{\circ} \mathrm{C}$ and the mean weight remaining calculated at approximately $20 \mathrm{~d}$ intervals. All data are mean percentage weight values \pm standard error of the mean of 7 replicate measurements.

In contrast, little degradation of PLA was observed either in soil or compost at $25^{\circ} \mathrm{C}$ or $37^{\circ} \mathrm{C}$ and degradation at $50^{\circ} \mathrm{C}$ only began rapidly after approximately 18 weeks. Fukushima et al. (2009) reported a significant reduction in the molecular weight of PLA when incubated in compost at $40^{\circ} \mathrm{C}$ for 17 weeks indicating significant depolymerisation. Moreover, it was shown that a significant weight loss in PLA was not observed until depolymerisation had occurred (Karamanlioglu and Robson, 2013). Likewise, it has been shown that breakdown of PHB was more enhanced by incubation of the polymer at higher 
temperatures (Mergaert et al., 1994). Slow degradation of PBS (in comparison

369 to PHB and PCL) has also previously been reported (Nishide et al., 1999). A key factor in this present study with regard to comparison with previous studies

371

372 was the size and thickness of the disc used, here with an average thickness of $3 \mathrm{~mm}$, in comparison to a much thinner polymer film (typically $0.2 \mathrm{~mm}$ thick) used in many other studies. Increased polymer thickness will greatly reduce the total contact between hydrolytic enzymes and the total surface area of the sample, thereby reducing degradation rate (Yang et al., 2005).

\subsection{Degradation of polymer discs buried in soil under uncontrolled} environmental conditions

Following on from the information gained from the first experiment showing differential degradation of the PCL, PHB, PLA and PBS polymers in compost and soil under controlled conditions, a second experiment aimed to compare the rate of degradation of the four polymers under natural environmental conditions. Therefore thick PCL, PHB, PLA and PBS discs were buried outside in natural soil then visualised and weighed over a period of 21 months. Control (unburied) discs were incubated in dry conditions at room temperature while additional control discs were placed in sterile water at room temperature. There was no significant difference in the weight of unburied discs for all polymers over the duration of 21 months (Fig. 3). Likewise, there was no weight change for discs incubated in water. There was no significant weight loss for the buried PHB, PLA and PBS discs but a significant reduction for the PCL discs (Fig. 3a). There was clear evidence of substantial fungal growth on the 

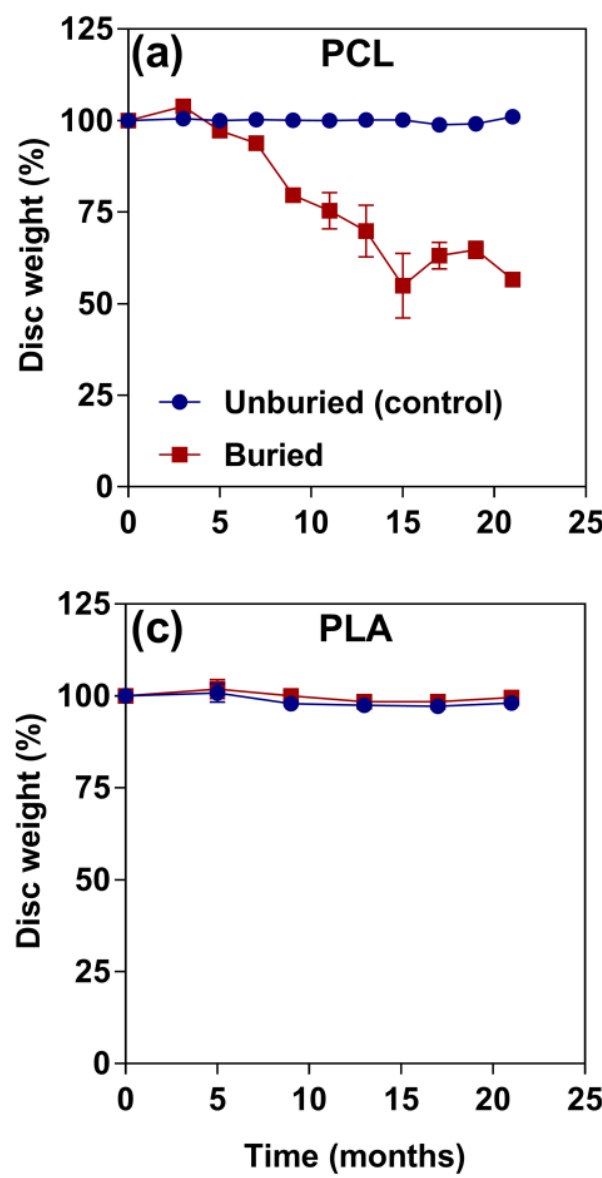
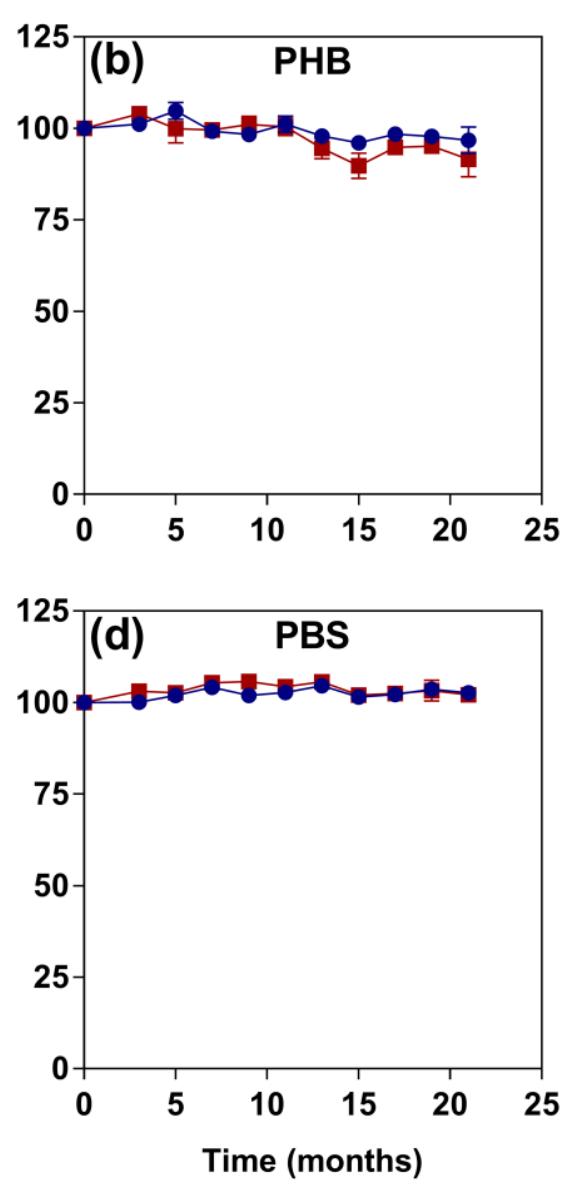

surface of the PCL discs and some growth on the PBS discs, but PHB and PLA discs showed the least visual change (Supplementary Data Fig. S1).

Fig. 3. Weight change over time of polymer discs buried in soil under uncontrolled environmental conditions. PCL (a), PHB (b), PLA (c) and PBS (d) discs were buried in soil in a field environment and the mean weight remaining calculated at approximately 2 - 4 month intervals. Unburied (control) samples were kept dry at room temperature. All data are mean percentage weight values \pm standard error of the mean of 3 replicate measurements.

Few studies have examined polymer degradation under natural conditions, but such understanding is very important in order to determine the nature and conditions of the environment where polymers can be disposed or where landfill sites should be made. The distinction in response of different polymers to natural field conditions in comparison to controlled soil and compost 
408 incubations is likely explained in part by the differential temperature sensitivity 409 of the polymers. The degradation of PCL only is likely explained by its higher degradation rate at the lower temperature of $25^{\circ} \mathrm{C}$ in soil (Fig. 2). However, other environmental factors that may explain the enhanced breakdown of this polymer cannot be discounted. PBS was also previously found to have significantly higher degradation in compost rather than natural soil because of the increased temperature and humidity conditions in the controlled chamber containing the compost (Kim et al., 2006). Likewise, degradation of PLA in a real soil environment over 11 months was very slow compared to a biopolymer such as cellulose, and this correlated to the low temperature of the natural environment (Rudnik and Briassoulis, 2011). Soil pH is also an important factor since this will also determine microbial activity (Emadian et al., 2017). It has also been argued that microbes that mediate the degradation of some polymers such as PBS are less common than microbes that can degrade polymers such as PCL (Ishii et al., 2008).

\subsection{Loss of residual PCL powder following compost incubation}

Since there was substantial weight loss of PCL polymer in compost in comparison to the other polymers, the breakdown of PCL in different geometric 427 forms was further examined. First this was tested by quantifying degradation of 428 very small $(<600 \mu \mathrm{m}) \mathrm{PCL}$ granules. This is relevant since many plastics are often fragmented or degraded, such as by weathering, into much smaller microplastics and it is of interest to determine whether such PCL microplastics are also efficiently degraded in compost. PCL powder was mixed with compost 
432 to give a concentration of $10 \%$ PCL. The compost was again incubated at a 433 range of temperatures, this time including up to $55^{\circ} \mathrm{C}$. As seen by loss in $\mathrm{PCL}$ 434 disc weight, incubation at the higher temperatures of $45^{\circ} \mathrm{C}$ and $50^{\circ} \mathrm{C}$ also gave 435 rise to greater degradation of PCL powder, as indicated by substantial loss of 436 residual $\mathrm{PCL}$, in comparison to the more moderate reduction at $25^{\circ} \mathrm{C}$ and $37^{\circ} \mathrm{C}$ 437 (Fig. 4). Degradation of the powder was rapid compared to the rate of 438 degradation of the thick PCL discs in compost (Fig. 1a). The larger, thicker 439 discs will initially be degraded by slower surface erosion. Furthermore, the small

440 PCL powder granules will have increased surface area for colonization and 441 degradation by microorganisms compared to the thick discs. Likewise, polymer 442 geometries with a higher surface area to volume ratio will degrade faster 443 (Bölgen et al., 2005). Surprisingly, the highest temperature of $55^{\circ} \mathrm{C}$ gave a slow 444 degradation profile that was equivalent to the $25^{\circ} \mathrm{C}$ treatment. This might relate 445 to the potential reduced abundance of microbial communities within the 446 compost that can tolerate the higher temperature of $55^{\circ} \mathrm{C}$. For example, fewer 447 species of fungi have the ability to survive at temperatures between $45^{\circ} \mathrm{C}$ and $44855^{\circ} \mathrm{C}$ (Maheshwari et al., 2000). Again this would indicate the importance of 449 microbial activity rather than increased temperature itself for the degradation of 450 the PCL polymer. 


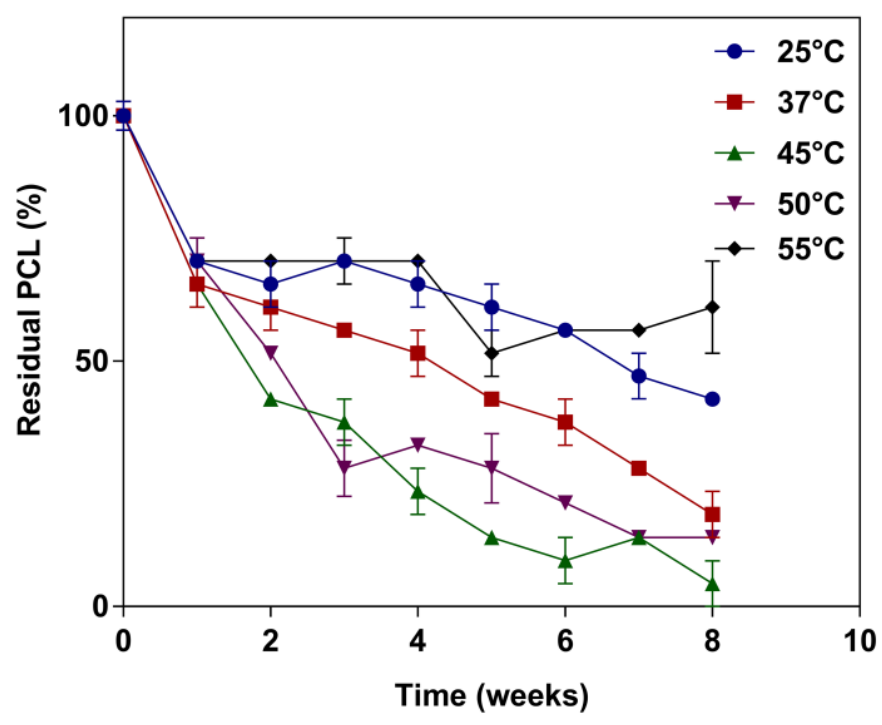

452

Fig. 4. Mean percentage of residual $P C L$ powder remaining over time following incubation in compost. $10 \% \mathrm{PCL}$ in compost was incubated at five different temperatures and recovered at 1 week intervals over 8 weeks for quantification. All data are mean percentage weight values \pm standard error of the mean of 3 replicate measurements.

3.4. Loss of tensile strength of PCL strips following compost incubation

For the final method of characterization of PCL polymer degradation, a

change in the mechanical properties of thin strips of PCL following compost

incubation was quantified by use of maximum tensile strength measurement.

There was a significant decrease in the tensile strength of all PCL strips incubated in compost (Fig. 5). This significant loss of strength was apparent by Week 5 for the strips incubated at $25^{\circ} \mathrm{C}$ and $37^{\circ} \mathrm{C}$, and a near complete loss of tensile strength by the end of the burial period (Week 10) when the tensile strength reached $0.51 \mathrm{MPa}$ after incubation at $25^{\circ} \mathrm{C}$ and $1.31 \mathrm{MPa}$ after incubation at $37^{\circ} \mathrm{C}$. This was in contrast to the tensile strength value before compost incubation, which was 14.18 MPa. Incubation at the two higher temperatures led to rapid loss in tensile strength of the strips, and a significant reduction by Week 2 (Fig. 5). At $45^{\circ} \mathrm{C}$ no intact strips could be recovered after 8 
472 weeks, while at $50^{\circ} \mathrm{C}$ no intact strips could be recovered after 5 weeks. The loss

473 of tensile strength at the lower temperatures was linear over time, indicating

474 predominant surface erosion, while the curve profiles at $45^{\circ} \mathrm{C}$ and $50^{\circ} \mathrm{C}$ showed

475 exponential decay (Fig. 5) indicative of bulk erosion (Göpferich, 1996). Control

476 strips incubated dry, or in a compost extract for 10 weeks at the different

477 temperatures showed no significant change in the tensile strength compared to

478 the Week 0 value. This indicates that the polymer was mainly being degraded

479 due to microbial action but not substantially due to abiotic hydrolytic

480 disintegration, and not simply due to temperature. This further indicates a link

481 between microbial activities at the higher temperatures facilitating PCL

482

hydrolysis. Enzymatic activities will also be temperature dependent (Haider et al

483 2019).

484

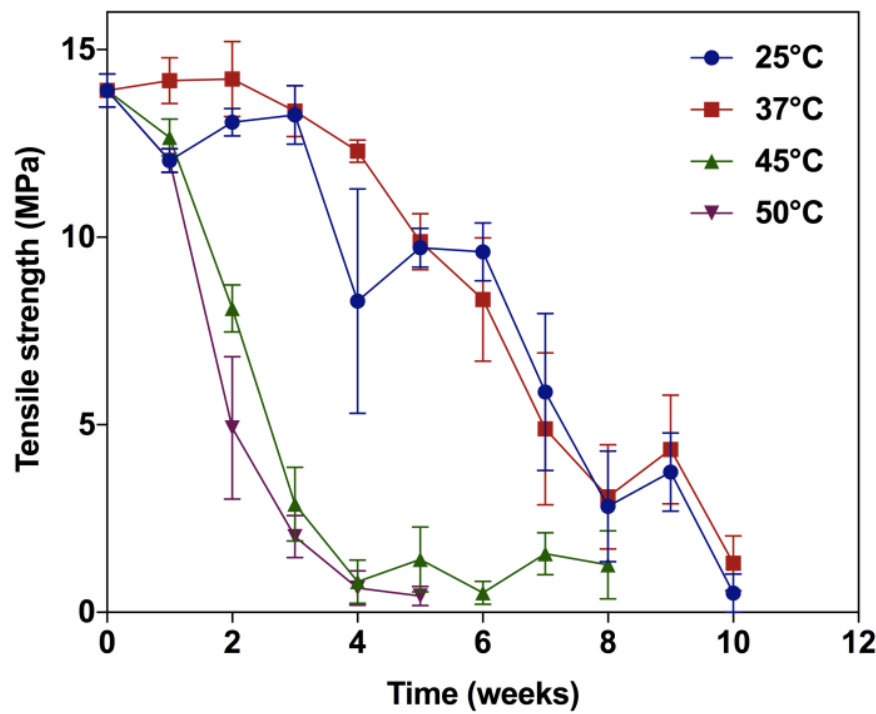

485

Fig. 5. Tensile strength measurements of PCL strips incubated in compost over time. PCL strips that were buried in compost at four different temperatures were recovered at 1 week intervals over 10 weeks for tensile strength measurement. At $45^{\circ} \mathrm{C}$ and $50^{\circ} \mathrm{C}$ the strips could be recovered only for 8 and 5 weeks, respectively before all strips were fully degraded. All data are mean values \pm standard error of the mean of 4 replicate measurements. 
(a) PCL
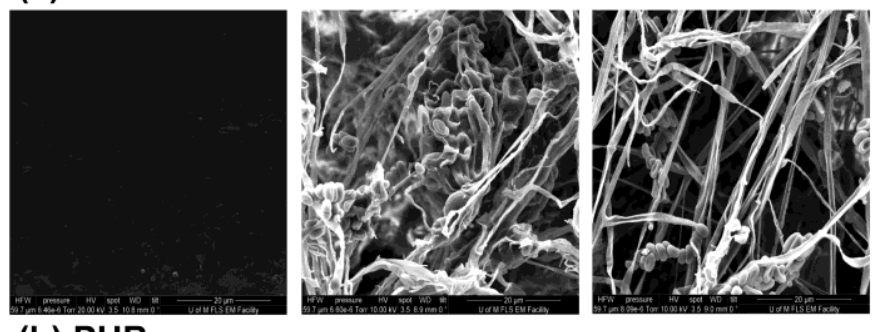

(b) PHB
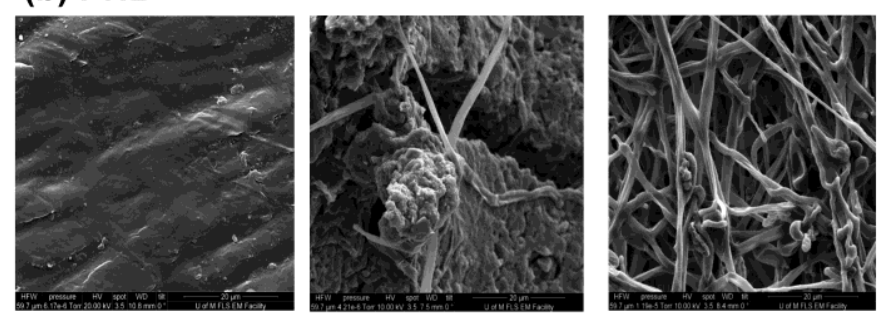

(c) PLA
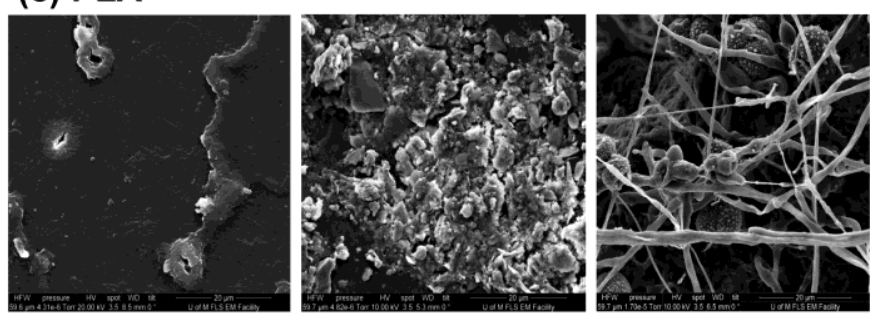

(d) PBS

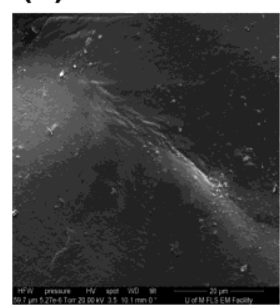

Control discs

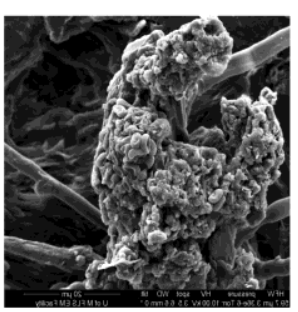

Soil $\left(25^{\circ} \mathrm{C}\right)$

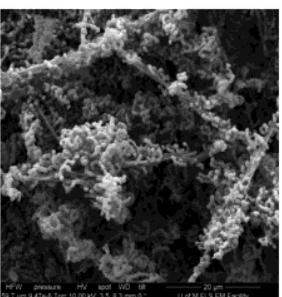

Compost $\left(50^{\circ} \mathrm{C}\right)$
494

495

496

497

498

499

500

501

502

503

504

Fig. 6. Fungal growth on the surface of polymer discs visualised by SEM. PCL (a), PHB (b), PLA (c) and PBS (d) discs were buried in soil at $25^{\circ} \mathrm{C}$ or compost at $50^{\circ} \mathrm{C}$ and discs were recovered for analysis. Unburied control discs from a dry indoor environment were compared to confirm for no background fungal growth.

\subsection{Identification of fungal strains recovered from the surface of polymer discs}

buried in soil and compost

Visual inspection of recovered polymer discs indicated the presence of

fungal growth (Supplementary Data Fig. S1). A more detailed analysis by SEM

clearly showed fungal growth on the surface of all polymer discs following 
505 incubation in soil and compost (Fig. 6). The different polymers and the different substrates (soil versus compost) yielded fungal growth with different morphological characteristics. In contrast, the control discs that were left unburied at room temperature were clear and had no fungal growth. A variety of microorganisms use the polymers as nutrients, particularly when under starvation and lacking essential nutrition (Roohi et al., 2017), thus they play a crucial role in the degradation of the polymers. However, there is a scarcity of information with regard to the organisms that are responsible for biodegradation (Suyama and Tokiwa, 1998).

Random discs were chosen from each substrate at each temperature for the isolation of the fungal strains. The discs were chosen according their appearance and how much fungi covered them. After fungal isolation and growth on PDA plates, distinct morphotypes were identified based on morphological variation of colonies (Supplementary Data Table S4). Only PCL discs provided fungal growth from all treatments with 1 - 3 morphotypes, followed PHB discs with $1-2$ morphotypes from all treatments apart from $25^{\circ} \mathrm{C}$ soil. Fungi (3 morphotypes) could only be recovered from PLA discs from $50^{\circ} \mathrm{C}$ compost, and PBS discs provided just one morphotype each from $50^{\circ} \mathrm{C}$ compost and from $37^{\circ} \mathrm{C}$ soil. performed. Most of the thermophilic isolates recovered from the surface of the PCL, PLA and PHB discs buried in compost at $50^{\circ} \mathrm{C}$ were identified as

527 Thermomyces lanuginosus, with the exception of one isolate recovered from PBS, which could not be defined to a single species (Table 1). For the polymer 
529 discs incubated at the lower temperatures, the most frequently recovered

530 isolates were strains of Aspergillus fumigatus (Table 1). Isolates that were

531 strains of Fusarium sp. were recovered from $\mathrm{PCL}$ and $\mathrm{PHB}$ at $25^{\circ} \mathrm{C}$ in both

532 compost and soil. Furthermore, a strain that was identified as Neocosmospora

533 sp. was found on the surface of $\mathrm{PCL}$ at $25^{\circ} \mathrm{C}$ in compost.

$534 T$. lanuginosus is a thermophilic fungus found in many habitats, with an

535 optimum growth temperature of $50^{\circ} \mathrm{C}$. T. lanuginosus produces heat-stable

536 enzymes that can tolerate high temperatures in comparison to those produced

537 by mesophiles (Singh et al, 2003). Previously T. lanuginosus was identified as

538 the most frequently recovered isolate from the surface of PLA buried in compost

539 at $50^{\circ} \mathrm{C}$ (Karamanlioglu et al., 2014). There is an important need to isolate

540 thermophilic microorganisms that are capable of degrading polymers because

541 of their importance in the composting process, which is considered as one of

542 the most promising technologies in biodegradable polymer recycling (Chua et

543 al., 2013; Tseng et al., 2007). In contrast, mesophilic fungi Aspergillus and

544 Fusarium were previously found to be important degrading microorganisms of

545 PCL (Chua et al., 2013). Both A. fumigatus and F. solani were also previously

546 isolated from the surface of PLA when incubated at $25^{\circ} \mathrm{C}$ in soil and compost

547 (Karamanlioglu et al., 2014). 
Table 1. Fungal taxa assignments identified using ITS sequencing of rRNA gene amplified from samples isolated from the surface of polymer discs buried in soil and compost under controlled conditions. The closest sequence matches from the NCBI GenBank database determined by BLAST are shown.

554

$\begin{array}{ccc}\begin{array}{c}\text { Polymer and } \\ \text { isolate } \\ \text { condition }\end{array} & \begin{array}{c}\text { Strain } \\ \text { isolate } \\ \text { name }\end{array} & \text { Strain identification } \\ & & \end{array}$

\begin{tabular}{|c|c|c|c|}
\hline $\mathrm{PCL}$ & $\mathrm{PCL}(\mathrm{A})$ & Thermomvces lanuainosus & $99 \%(K T 3652291)$ \\
\hline \multirow{2}{*}{ Compost $50^{\circ} \mathrm{C}$} & PCL(B) & Thermomyces lanuginosus & $98 \%(\mathrm{KY} 848520.1)$ \\
\hline & PCL(C) & Thermomyces lanuginosus & 99\% (KT365229.1) \\
\hline \multirow{5}{*}{$\begin{array}{l}\text { PHB } \\
\text { Compost } 50^{\circ} \mathrm{C}\end{array}$} & $\mathrm{PHB}(\mathrm{H})$ & Thermomyces lanuginosus & 99\% (KT365229.1) \\
\hline & $\mathrm{PHB}(\mathrm{I})$ & Undefined strain: & \\
\hline & & Sordariales sp. & 99\% (JN659492.1) \\
\hline & & Scytalidium thermophilum & $99 \%(A B 085928.1)$ \\
\hline & & Chaetomium thermophilum & $99 \%(A B 746179.1)$ \\
\hline PLA & PLA(E) & Thermomyces lanuginosus & 97\% (KT365229.1) \\
\hline \multirow[t]{2}{*}{ Compost $50^{\circ} \mathrm{C}$} & $\operatorname{PLA}(\mathrm{F})$ & Thermomyces lanuginosus & 99\% (KT365229.1) \\
\hline & $\operatorname{PLA}(\mathrm{G})$ & Sordariales sp. & 100\% (JN659504.1) \\
\hline PBS & PBS(K) & Undefined strain: & \\
\hline \multirow[t]{3}{*}{ Compost $50^{\circ} \mathrm{C}$} & & Talaromyces pinophilus & 99\% (MF686817.1) \\
\hline & & Acremonium cellulolyticus & $99 \%(A B 474749.2)$ \\
\hline & & Penicillium pinophilum & $99 \%(A B 474749.2)$ \\
\hline PCL & PCL(N) & Aspergillus fumigatus & 99\% (KX090325.1) \\
\hline Compost $37^{\circ} \mathrm{C}$ & $\mathrm{PCL}(\mathrm{O})$ & Aspergillus fumigatus & $98 \%(K X 090348.1)$ \\
\hline \multicolumn{4}{|l|}{ Compost $37^{\circ} \mathrm{C}$} \\
\hline$\overline{\mathrm{PCL}}$ & $\mathrm{PCL}(\mathrm{P})$ & Aspergillus fumigatus & $100 \%(\mathrm{KY} 450779.1)$ \\
\hline Soil $37^{\circ} \mathrm{C}$ & $\operatorname{PCL}(X)$ & Aspergillus fumigatus & $99 \%\left(K^{\prime} 527135.1\right)^{\prime}$ \\
\hline $\begin{array}{l}\text { PHB } \\
\text { Soil } 37^{\circ} \mathrm{C}\end{array}$ & $\mathrm{PHB}(\mathrm{M})$ & Aspergillus fumigatus & 99\% (KP724998.1) \\
\hline $\begin{array}{l}\text { PBS } \\
\text { Soil } 37^{\circ} \mathrm{C}\end{array}$ & PBS(L) & Aspergillus fumigatus & $100 \%($ KF494830.1) \\
\hline PCL & $\mathrm{PCL}(\mathrm{Q})$ & Neocosmospora ramosa & 99\% (KY031973.1) \\
\hline \multirow[t]{2}{*}{ Compost $25^{\circ} \mathrm{C}$} & PCL(R) & Fusarium solani & 99\% (KX929306.1) \\
\hline & PCL(S) & Aspergillus fumigatus & 99\% (KP724998.1) \\
\hline PHB & $\mathrm{PHB}(\mathrm{V})$ & Fusarium solani & $99 \%(K X 929306.1)$ \\
\hline Compost $25^{\circ} \mathrm{C}$ & $\mathrm{PHB}(\mathrm{W})$ & Aspergillus fumigatus & $100 \%(K X 090348.1)$ \\
\hline $\mathrm{PCL}$ & $\mathrm{PCL}(\mathrm{T})$ & Aspergillus fumigatus & $100 \%($ KR527135.1) \\
\hline Soil $25^{\circ} \mathrm{C}$ & PCL(U) & Fusarium solani & 99\% (KM268689.1) \\
\hline
\end{tabular}


Microorganisms will adhere to the polymer surface making a biofilm and

557 become responsible for the degradation of polymers by utilizing the hydrocarbons in the polymer backbone as a carbon source. The PCL discs attracted a significant amount of fungal biomass as determined from visual observations (Fig. 6; Supplementary Data Fig. S1) and had the greatest diversity of fungal taxa (Supplementary Data Table S4), but it is unclear what structural properties explain this. Hydrophobicity of the polymer surface is one key factor determining microbial attachment (Sarjit et al., 2015). Degradation of a number of polyester biodegradable plastics including those used in this study have been shown to be mediated by microbial extracellular esterases including lipases and cutinases causing hydrolysis of the ester linkages and progressive depolymerisation (Ishii et al., 2008; Nakamura et al., 2001; Numata et al., 2007; Shah et al., 2008; Tokiwa et al., 2009). Enzymatic degradation will be preferential in amorphous regions of the polymer but can also occur within crystalline regions (Castilla-Cortázar et al., 2012). Moreover, the molecular weight can influence the enzymatic biodegradation process such that the degradability will decrease with increased molecular weight. For example, high molecular weight PCL displays slower degradation by Rhizopus delemar lipase

574 than low molecular weight PCL (Tokiwa et al., 2009).

\subsection{PCL degradation by Thermomyces lanuginosus strains}

PCL is known to be degraded at high temperature by bacteria (Emadian et al., 2017) but there have been no previous identification of fungal strains able to degrade PCL at high temperatures. The ability of the isolated $T$. lanuginosus 
580

581

582

583

584

585

586

587

588

589

590

591

592

593

594

595

596

597

598

599

600

strains to degrade $\mathrm{PCL}$ at $50^{\circ} \mathrm{C}$ were investigated. Once again tensile strength measurement of thin PCL strips was quantified since this parameter allows accurate analysis of degradation rate over short time periods. Two strains named $P C L(A)$ and $P C L(B)$ were tested for their ability to degrade PCL strips using tensile strength measurements following 3-week incubation. Control strips incubated in growth medium without any fungal inoculation showed insignificant change in tensile strength. However, tensile strength of PCL strips incubated in the growth medium inoculated with the PCL(B) strain reduced significantly after just $3 \mathrm{~d}$ and dropped to approximately $3 \mathrm{MPa}$ in $6 \mathrm{~d}$ in comparison to an initial tensile strength of approximately $14 \mathrm{MPa}$ (Fig. 7). The reduction in tensile strength of the PCL strips incubated with the PCL(A) strain was not as fast but the degradation of PCL was nevertheless significantly enhanced compared to the control strips. The profile of degradation was equivalent to the incubation of the PCL strips in compost at $50^{\circ} \mathrm{C}$, which shows exponential loss of tensile strength, however, the degradation rate was faster when the strips were incubated with the purified fungal strain (Fig. 7). This result clearly indicates that T. lanuginosus strains are capable of degradation of $\mathrm{PCL}$ at $50^{\circ} \mathrm{C}$, and also suggests that the degradation induced by $T$. lanuginosus is largely mediating bulk erosion of the polymer. Future studies will aim towards identifying the exact mechanisms of $T$. lanuginosus induced degradation. 


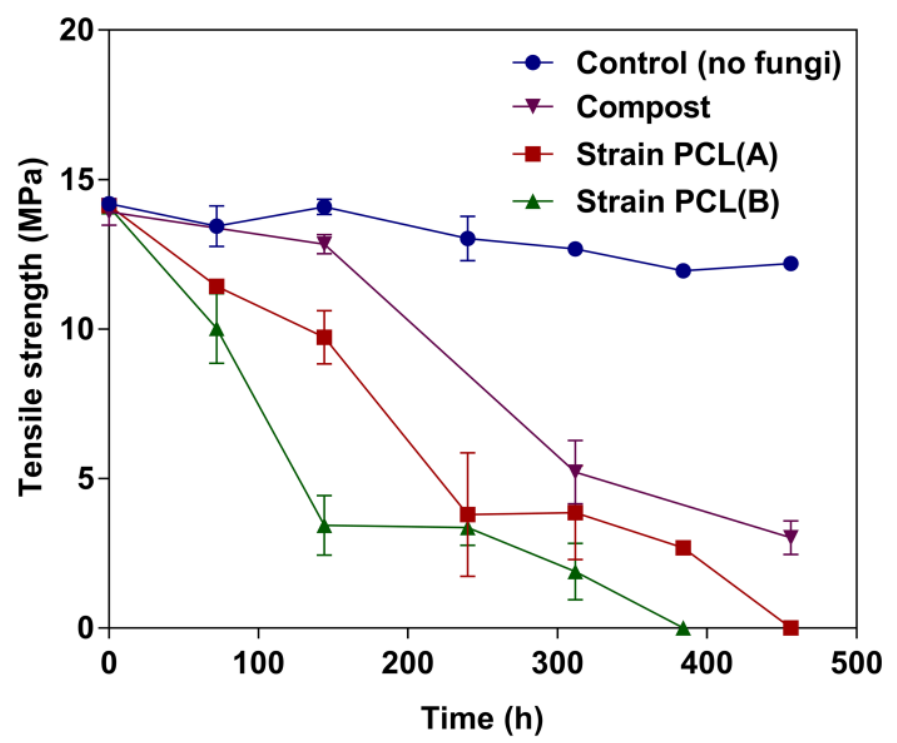

601

Fig. 7. The ability of fungal strains isolated from the surface of $P C L$ in compost at $50^{\circ} \mathrm{C}$

602

603

604

605

606

607

608

609

610

611

612

613

614

615

616

617

618

619 to degrade PCL strips. Tensile strength data after $18 \mathrm{~d}$ incubation with Thermomyces lanuginosus strains $\mathrm{PCL}(\mathrm{A})$ and $\mathrm{PCL}(\mathrm{B})$ at $50^{\circ} \mathrm{C}$. All data are mean values \pm standard error of the mean of 3 replicate measurements.

\section{Conclusions}

With the increasing production and consumption of plastics in daily life, and the consequences of their disposal, there is a need to introduce new plastics that are environmentally friendly. The rate of biodegradation of four biodegradable polymers was investigated under controlled conditions and within the natural environment. Under both conditions PCL demonstrated more rapid degradation compared to PLA, PHB and PBS. Temperature was highly correlated to the rate of PCL degradation under controlled conditions due to microbial activity. Strains of $T$. lanuginosus grow on all tested polymers at high teperature, and are directly responsible for the degradation of PCL. 


\section{Competing interests}

The authors declare that they have no competing interests.

\section{Acknowledgements}

ASA thanks the Sultanate of Oman for providing a PhD scholarship. This research did not receive any specific grant from funding agencies in the public, commercial, or not-for-profit sectors. We are grateful to the FBMH University of Manchester Electron Microscopy Unit for performing SEM analysis. We dedicate this paper to the memory of Dr Geoff Robson.

\section{Appendix A. Supplementary data}

The supplementary data contains Supplementary Fig. S1 and Supplementary Table S1 - S4.

\section{References}

Albertsson, A.C., Renstad, R., Erlandsson, B., Eldsater, C., Karlsson, S., 1998. Effect of processing additives on (bio)degradability of film-blown poly( $\mathcal{E}$ caprolactone). J. Appl. Polym. Sci. 70, 61-74.

Bölgen, N., Menceloğlu, Y. Z., Acatay, K, Vargel, I., Pişkin, E., 2005. In vitro and in vivo degradation of non-woven materials made of poly $(\varepsilon-$ caprolactone) nanofibers prepared by electrospinning under different conditions. J. Biomater. Sci. Polym. Edn. 16, 1537-1555.

Borghesi, D.C., Molina, M.F., Guerra, M.A., Campos, M.G.N., 2016. 
Biodegradation study of a novel poly-caprolactone-coffee husk composite film. Mater. Res. 19, 752-758.

Castilla-Cortázar, I., Más-Estellés, J., Meseguer-Dueñas, J.M., Escobar Ivirico, J.L., Marí, B., Vidaurre, A., 2010. Hydrolytic and enzymatic degradation of a poly( $\varepsilon$-caprolactone) network. Polym. Degrad. Stabil. 97, 1241-1248.

Chandra, R., Rustgi, R., 1998. Biodegradable polymers. Prog. Polym. Sci. 23, 1273-1335.

Chua, T.K., Tseng, M., Yang, M.K., 2013. Degradation of Poly( $\varepsilon$-caprolactone) by thermophilic Streptomyces thermoviolaceus subsp. thermoviolaceus 76T-2. AMB Express 3, 8.

Cosgrove, L., McGeechan, P.L., Handley, P.S., Robson, G.D., 2010. Effect of biostimulation and bioaugmentation on degradation of polyurethane buried in soil. Appl. Environ. Microbiol. 76, 810-819.

Cosgrove, L., McGeechan, P.L., Robson, G.D., Handley, P.S., 2007. Fungal communities associated with degradation of polyester polyurethane in soil. Appl. Environ. Microbiol. 73, 5817-5824.

Crabbe, J.R., Campbell, J.R., Thompson, L., Walz, S.L., Schultz, W.W., 1994. Biodegradation of a colloidal ester-based polyurethane by soil fungi. Int. Biodeter. Biodegr. 33, 103-113.

Emadian, S.M., Onay, T.T., Demirel, B., 2017. Biodegradation of bioplastics in natural environments. Waste Manage. 59, 526-536.

Feng, J., Hwang, R., Chang, K.F., Hwang, S.F., Strelkov, S.E., Gossen, B.D., Zhou, Q., 2010. An inexpensive method for extraction of genomic DNA from fungal mycelia. Can. J. Plant Pathol. 32, 396-401. 
667 Fukushima, K., Abbate, C., Tabuani, D., Gennari, M., Camino, G., 2009.

668

669

670

671

672

673

674

675

676

677

678

679

680

681

682

683

684

685

686

687

688

689

690

Biodegradation of poly(lactic acid) and its nanocomposites. Polym.

Degrad. Stabil. 94, 1646-1655.

Fukushima, K., Abbate, C., Tabuani, D., Gennari, M., Rizzarelli, P., Camino, G., 2010. Biodegradation trend of poly( $\varepsilon$-caprolactone) and nanocomposites. Mater. Sci. Eng. C 30, 566-574.

Funabashi, M., Ninomiya, F., Kunioka, M., 2007. Biodegradation of polycaprolactone powders proposed as reference test materials for international standard of biodegradation evaluation method. J. Polym. Environ. 15, 7-17.

Göpferich, A., 1996. Mechanisms of polymer degradation and erosion. Biomaterials 17, 103-114.

Haider, T.P., Völker, C., Kramm, J., Landfester, K., Wurm, F.R., 2019. Plastics of the future? The impact of biodegradable polymers on the environment and on society. Angew. Chem. Int. Edit. 58, 50-62.

Hopewell, J., Dvorak, R., Kosior, E., 2009. Plastics recycling: challenges and opportunities. Philos. Trans. Royal Soc. B 364, 2115-2126.

Ishii, N., Inoue, Y., Tagaya, T., Mitomo, H., Nagai, D., Kasuya, K.I., 2008. Isolation and characterization of poly(butylene succinate)-degrading fungi. Polym. Degrad. Stabil. 93, 883-888.

Karamanlioglu, M., Houlden, A., Robson, G.D., 2014. Isolation and characterisation of fungal communities associated with degradation and growth on the surface of poly (lactic) acid (PLA) in soil and compost. Int. Biodeter. Biodegr. 95, 301-310. 
691 Karamanlioglu, M., Preziosi, R., Robson, G.D., 2017. Abiotic and biotic

692

693

694

695

696

697

698

699

700

701

702

703

704

705

706

707

708

709

710

711

712

713

714 environmental degradation of the bioplastic polymer poly(lactic acid): A review. Polym. Degrad. Stabil. 137, 122-130.

Karamanlioglu, M., Robson, G.D., 2013. The influence of biotic and abiotic factors on the rate of degradation of poly(lactic) acid (PLA) coupons buried in compost and soil. Polym. Degrad. Stabil. 98, 2063-2071.

Kim, H.S., Kim, H.J., Lee, J.W., Choi, I.G., 2006. Biodegradability of bio-flour filled biodegradable poly(butylene succinate) bio-composites in natural and compost soil. Polym. Degrad. Stabil. 91, 1117-1127.

Kim, H.S., Yang, H.S., Kim, H.J., 2005. Biodegradability and mechanical properties of agro-flour-filled polybutylene succinate biocomposites. J. Appl. Polym. Sci. 97, 1513-1521.

Laycock, B., Nikolić, M., Colwell, J.M., Gauthier, E., Halley, P., Bottle, S., George, G., 2017. Lifetime prediction of biodegradable polymers. Prog. Polym. Sci. 71, 144-189.

Li, F., Yu, D., Lin, X., Liu, D., Xia, H., Chen, S., 2012. Biodegradation of poly(Ecaprolactone) (PCL) by a new Penicillium oxalicum strain DSYD05-1. World J. Microbiol. Biotechnol. 28, 2929-2935.

Luyt, A.S., Malik, S.S., 2019. Can Biodegradable Plastics Solve Plastic Solid Waste Accumulation?, in: Al-Salem, S.M. (Ed.), Plastics to Energy: Fuel, Chemicals, and Sustainability Implications. William Andrew Publishing, Norwich, pp. 403-423.

Maheshwari, R., Bharadwaj, G., Bhat, M.K., 2000. Thermophilic fungi: their physiology and enzymes. Microbiol. Mol. Biol. Rev. 64, 461-88. 
Manna, A., Paul, A.K., 2000. Degradation of microbial polyester poly(3hydroxybutyrate) in environmental samples and in culture. Biodegradation 11, 323-329.

Nakamura, K., Tomita, T., Abe, N., 2001. Purification and characterization of an extracellular poly (I-lactic acid) depolymerase from a soil isolate, Amycolatopsis sp. strain K104-1. Appl. Environ. Microbiol. 67, 345-353.

Nampoothiri, K.M., Nair, N.R., John, R.P., 2010. An overview of the recent developments in polylactide (PLA) research. Bioresour. Technol. 101, 8493-501.

Nawaz, A., Hasan, F., Shah, A.A., 2015. Degradation of poly( $\varepsilon$-caprolactone) (PCL) by a newly isolated Brevundimonas sp. strain MRL-AN1 from soil. FEMS Microbiol. Lett. 362, 1-7.

Nishide, H., Toyota, K., Kimura, M., 1999. Effects of soil temperature and anaerobiosis on degradation of biodegradable plastics in soil and their degrading microorganisms. Soil Sci. Plant Nutr. 45, 963-972.

Numata, K., Yamashita, K., Fujita, M., Tsuge, T., Kasuya, K. I., Iwata, T., Doi, Y., Abe, H., 2007. Adsorption and hydrolysis reactions of poly(hydroxybutyric acid) depolymerases secreted from Ralstonia pickettii T1 and Penicillium funiculosum onto poly[(R)-3-hydroxybutyric acid]. Biomacromolecules 8, 2276-2281.

Pranamuda, H., Tokiwa, Y., 1999. Degradation of poly(L-lactide) by strains belonging to genus Amycolatopsis. Biotechnol. Lett. 21, 901-905.

Reddy, C.S.K., Ghai, R., Rashmi, Kalia, V.C., 2003. Polyhydroxyalkanoates: an overview. Bioresour. Technol. 87, 137-146. 
739 Roohi, Bano, K., Kuddus, M., Zaheer, M.R., Zia, Q., Khan, M.F., Ashraf, G.M.,

740

741

742

743

744

745

746

747

748

749

750

751

752

753

754

755

756

757

758

759

760

761

762 Gupta, A., Aliev, G., 2017. Microbial enzymatic degradation of biodegradable plastics. Curr. Pharm. Biotechnol. 18, 429-440.

Rudnik, E., Briassoulis, D., 2011. Degradation behaviour of poly(lactic acid) films and fibres in soil under Mediterranean field conditions and laboratory simulations testing. Ind. Crop Prod. 33, 648-658.

Sarjit, A., Tan, S.M., Dykes, G.A., 2015. Surface modification of materials to encourage beneficial biofilm formation. AIMS Bioeng. 2, 404-422.

Shah, A.A., Hasan, F., Hameed, A., Ahmed, S., 2008. Biological degradation of plastics: a comprehensive review. Biotechnol. Adv. 26, 246-265.

Shimao, M., 2001. Biodegradation of plastics. Curr. Opin. Biotechnol. 12, 242247.

Singh, S., Madlala, A.M., Prior, B.A., 2003. Thermomyces lanuginosus: properties of strains and their hemicellulases. FEMS Microbiol. Rev. 27, 3-16.

Siracusa, V., Rocculi, P., Romani, S., Rosa, M.D., 2008. Biodegradable polymers for food packaging: a review. Trends Food Sci. Technol. 19, 634-643.

Song, J.H., Murphy, R.J., Narayan, R., Davies, G.B.H., 2009. Biodegradable and compostable alternatives to conventional plastics. Philos. Trans. Royal Soc. B 364, 2127-2139.

Suyama, T., Tokiwa, Y., 1998. Phylogenetic affiliation of soil bacteria that degrade aliphatic polyesters available commercially as biodegradable plastics. Appl. Environ. Microbiol. 64, 1-5. 
763 Tokiwa, Y., Calabia, B.P., Ugwu, C.U., Aiba, S., 2009. Biodegradability of plastics. Int. J. Mol. Sci., 10, 3722-3742.

765

766

767

768

769

770

771

772

773

774

775

776

777

778

779

780

781

782

783

Tseng, M., Hoang, K.C., Yang, M.K., Yang, S.F., Chu, W.S., 2007. Polyesterdegrading thermophilic actinomycetes isolated from different environment in Taiwan. Biodegradation 18, 579-583.

Tsuji, H., Miyauchi, S., 2001. Poly(L-lactide) 6. Effects of crystallinity on enzymatic hydrolysis of poly(l-lactide) without free amorphous region. Polym. Degrad. Stab. 71, 415-424.

Vivi, V.K., Martins-Franchetti, S.M., Attili-Angelis, D., 2019. Biodegradation of PCL and PVC: Chaetomium globosum (ATCC 16021) activity. Folia Microbiol. 64, 1-7.

White, T.J., Bruns, T., Lee, S., Taylor, J., 1990. Amplification and sequencing of fungal ribosomal RNA genes for phylogenetics, in: Innis, M.A., Gelfand, D.H., Sninsky, J.J., White, T.J. (Eds.), PCR Protocols: A Guide to Methods and Applications. Academic Press, San Diego, pp. 315-322.

Yang, H.S., Yoon, J.S., Kim, M.N., 2005. Dependence of biodegradability of plastics in compost on the shape of specimens. Polym. Degrad. Stabil. $87,131-135$.

Zheng, Y., Yanful, E.K., Bassi, A.S., 2005. A review of plastic waste biodegradation. Crit. Rev. Biotechnol. 25, 243-250. 


\section{Figure legends}

785

786

787

Fig. 1. Weight change over time of polymer discs buried in compost. PCL (a), PHB (b), PLA (c) and PBS (d) discs were buried in compost in a laboratory microcosm and incubated at $25^{\circ} \mathrm{C}, 37^{\circ} \mathrm{C}$ or $50^{\circ} \mathrm{C}$ and the mean weight remaining calculated at approximately $7 \mathrm{~d}$ intervals. All data are mean percentage weight values \pm standard error of the mean of 7 replicate measurements.

792

Fig. 2. Weight change over time of polymer discs buried in soil. PCL (a), PHB 794 (b), PLA (c) and PBS (d) discs were buried in soil in a laboratory microcosm and incubated at $25^{\circ} \mathrm{C}$ or $37^{\circ} \mathrm{C}$ and the mean weight remaining calculated at approximately $20 \mathrm{~d}$ intervals. All data are mean percentage weight values \pm standard error of the mean of 7 replicate measurements.

Fig. 3. Weight change over time of polymer discs buried in soil under 800 uncontrolled environmental conditions. PCL (a), PHB (b), PLA (c) and PBS (d) discs were buried in soil in a field environment and the mean weight remaining calculated at approximately 2 - 4 month intervals. Unburied (control) samples were kept dry at room temperature. All data are mean percentage weight values $804 \pm$ standard error of the mean of 3 replicate measurements.

Fig. 4. Mean percentage of residual PCL powder remaining over time following 807 incubation in compost. $10 \% \mathrm{PCL}$ in compost was incubated at five different 
808 temperatures and recovered at 1 week intervals over 8 weeks for quantification.

809 All data are mean percentage weight \pm standard error of the mean values of 3

810 replicate measurements.

811

812 Fig. 5. Tensile strength measurements of PCL strips incubated in compost over

813 time. PCL strips that were buried in compost at four different temperatures were

814 recovered at 1 week intervals over 10 weeks for tensile strength measurement.

815 At $45^{\circ} \mathrm{C}$ and $50^{\circ} \mathrm{C}$ the strips could be recovered only for 8 and 5 weeks,

816 respectively before all strips were fully degraded. All data are mean values \pm

817 standard error of the mean of 4 replicate measurements.

818

819 Fig. 6. Fungal growth on the surface of polymer discs visualised by SEM. PCL

(a), PHB (b), PLA (c) and PBS (d) discs were buried in soil at $25^{\circ} \mathrm{C}$ or compost

821 at $50^{\circ} \mathrm{C}$ and discs were recovered for analysis. Unburied control discs from a 822 dry indoor environment were compared to confirm for no background fungal 823 growth.

824

825 Fig. 7. The ability of fungal strains isolated from the surface of PCL in compost 826 at $50^{\circ} \mathrm{C}$ to degrade $\mathrm{PCL}$ strips. Tensile strength data after $18 \mathrm{~d}$ incubation with 827 Thermomyces lanuginosus strains $\mathrm{PCL}(\mathrm{A})$ and $\mathrm{PCL}(\mathrm{B})$ at $50^{\circ} \mathrm{C}$. All data are 828 mean values \pm standard error of the mean of 3 replicate measurements. 